\title{
THE EFFECTS OF INCLUSIVE LEADERSHIP ON JOB PERFORMANCE THROUGH MEDIATORS
}

\author{
Phuong V. Nguyen ${ }^{*}$, Huyen Thi Ngoc Le², Thi Vu Anh Trinh ${ }^{1}$, and \\ Huynh Thi Sa Do ${ }^{1}$
}

${ }^{1}$ Center for Public Administration, International University, Vietnam National University-Ho Chi Minh City, Quarter 6, Linh Trung Ward,

Thu Duc District, Ho Chi Minh City 700000, Vietnam

${ }^{2}$ Van Hien University, 669 Dien Bien Phu Street, District 3, Ho Chi Minh City 700000, Vietnam

*Corresponding author: nvphuong@hcmiu.edu.vn

Published online: 30 December 2019

To cite this article: Nguyen, P.V., Le, H.T.N., Trinh, T.V.A., and Do, H.T.S. (2019). The effects of inclusive leadership on job performance through mediators. Asian Academy of Management Journal, 24(2), 63-94. https://doi.org/10.21315/aamj2019.24.2.4

To link to this article: https://doi.org/10.21315/aamj2019.24.2.4

\begin{abstract}
This study aims to investigate the direct effects of inclusive leadership on person-job fit, employee well-being, and innovative behaviour. It also extends existing research to observe the role of mutual recognition respect and intrinsic motivation in job performance. By using a structural equation model approach to analyse the data survey from 387 respondents, who were working at interior design and construction companies, the results revealed that inclusive leadership has a positive impact on key determinants such as employee well-being, person-job fit, and innovative behaviour. However, person-job fit and employee well-being had no significant direct impact on job performance. The study also identified the mediating role of innovative behaviour in the linkage between personjob fit and job performance. Moreover, the results recognised two potential mediators as mutual recognition respect and intrinsic motivation could create a relationship between employee well-being and job performance. The findings highlighted theoretical and empirical contributions to further understanding of the roles of leader-member exchange policies on job performance. Finally, some managerial implications were suggested to enhance job performance in the workplace.
\end{abstract}

Keywords: person-job fit, recognition respect, intrinsic motivation, employee well-being, job performance

(C) Asian Academy of Management and Penerbit Universiti Sains Malaysia, 2019. This work is licensed under the terms of the Creative Commons Attribution (CC BY) (http://creativecommons. org/licenses/by/4.0/). 


\section{INTRODUCTION}

The relationship between employee well-being and innovative behaviour has been explored (Scott \& Bruce, 1994). This relationship was considered as two progressively concerned predictors of organisational performance (Huhtala \& Parzefall, 2007). Among several potential drivers, leadership has a significant impact on employee well-being and innovative behaviour (Gong et al., 2009) through workplace social support, requirements, and control (Harris \& Kacmar, 2006). However, the linkages among particular styles of leadership, employee well-being, and innovative behaviour in a specific context have been rarely studied. Exceptionally, Sharifirad (2013) clarified transformational leadership as a strong influencer of employee well-being and innovative behaviour because of its motivational impacts on subordinators. Whereas, Fletcher (2004) suggested further research on underexplored leadership styles. Specifically, building a relationship between supervisors and subordinators create an inspiring workplace (Carmeli et al., 2010). Scholars suggested that future investigation on one core facet of relational leadership, which is inclusive leadership distinguished by three main characteristics of the leader: openness, availability, and accessibility in their interactions with employees, should be conducted (Hollander, 2009; Tims et al., 2011).

Previous studies have found the strong relationship between person-job fit and specific styles of leadership (Babakus et al., 2011), employee well-being (Brkich et al., 2002; Singh \& Greenhaus, 2004), and innovative behaviour (Afsar et al., 2014; Afsar et al., 2015). Indeed, the person-job fit has been identified as a mediator in the linkage between inclusive leadership and employee well-being and innovative behaviour (Choi et al., 2017; Sharifirad, 2013). The positive effect of inclusive leadership on employee well-being and innovative behaviour was discovered by Choi et al. (2017) in the Vietnamese telecommunication industry. As the study encouraged that future study should examine in other contexts with larger sample size to strengthen the findings, we attempt to enhance the finding in terms of the linkage between inclusive leadership, person-job fit, employee wellbeing, and innovative behaviour in interior design and construction industry. Also, there are several typical characteristics of interior design and construction industry in Vietnam, which are of primary importance for the research field. The market for interior goods and construction materials is getting more and more competitive in the past decade. In 2015, the total consumption expenditure of all households in Vietnam on household goods valued at $€ 10$ billion, which represented a $9 \%$ increase from 2014 and was expected to grow at the average rate of $9 \%$ for 2015-2020 (according to the report of Home and Décor sector in Vietnam, 2015). Many interior design and construction projects in Vietnam have made noticeable 
impressions on the global community platform Office Snapshots for interior designers.

The interior design and construction companies in Vietnam have achieved some global recognitions in terms of building design networks throughout training, creative, innovative, and experience activities. Also, consumer pressure and legal matters require more responsibility. As a result, interior design and construction companies face a challenge in attracting and retaining high-quality employees. It is companies that effectively motivate employees physically and psychologically obtain better and more innovative designs, strategies to compete in the dynamic and highly competitive interior market. Therefore, we conduct this study to clarify the feasible contribution that enhances employee job performance in this specific area.

Additionally, intrinsic motivation has been associated with higher job performance (Ryan \& Deci, 2000a) and employee well-being since individuals are better able to satisfy their three basic psychological needs of competence, relatedness, and autonomy (Ryan \& Deci, 2000b; Van den Broeck et al., 2013). In a recent study about the role of spiritual leadership in service industries in Vietnam, Nguyen et al. (2018) find that this leadership style has critical effects on organisational outcomes throughout meaning and calling, membership and empowerment.

In summary, previous studies have not investigated all dimensions of mediating variables of employee well-being, person-job fit, and innovative behaviour in examining the relationship between inclusive leadership and job performance. Therefore, to fulfill this gap, we investigated the effect of inclusive leadership on job performance through mediating factors. Our study attempts to solve these research questions:

1. Whether employee well-being, person-job fit, innovative behaviour, mutual recognition respect, and intrinsic motivation have any direct impact on job performance? Which are the most important determinants? Which factors are playing an essential role of mediators?

2. What is the influence of inclusive leadership on other factors that impact job performance?

Additionally, since mutual recognition respect and intrinsic motivation were found to foster job performance (Clarke \& Mahadi, 2017; Kuvaas et al., 2017), further investigation was conducted to test the potential mediating roles of the two above mentioned factors in the association between employee well-being and innovative 
behaviour and job performance. These newly explored mediators extend the existing literature in a distinctive context of the interior design and construction industry in Vietnam. This study consists of five sections: the literature review of related factors; methodology including measurement, questionnaire design, and data collection; results; discussion; and conclusion of the study's findings.

\section{LITERATURE REVIEW}

\section{Inclusive Leadership and Employee Well-being}

Locke (1976) asserted that employee well-being was a positive emotional state or pleasure coming from job appraisal or experience. Danna and Griffin (1999) discovered that effect, anxiety, and frustration were psychologically considered ideal well-being indicators, while heart condition, as well as blood pressure, were physiologically regarded as well-being indicators. Two different feelings to employee well-being are negative and positive, the former indicates burnout and occupational stress, whereas the latter is defined as an effective state including two dimensions: pleasure and level of arousal (Linley \& Joseph, 2004; Schaufeli \& Bakker, 2004; Cartwright \& Holmes, 2006). Therefore, this study follows the positive feeling and takes affective well-being as general well-being.

Inclusive leadership is considered one of the relational leaderships that leaders always concern employees' needs and are available to them (Hollander, 2009). From the elaboration on relational leadership, inclusive leadership is a form of relational leadership that leaders are willing to communicate employees' expectations and receive their feedback (Carmeli et al., 2010). This leadership is regarded as several other leadership styles, such as ethical leadership, servant leadership, and transformational leadership. Because it carries three aspects of supportive behaviours of a leader, involving availability, openness, and accessibility (Van Dierendonck, 2011). Although inclusive leadership is considered as one of the leadership styles, it motivates positive linkage qualities between leaders and followers (Choi et al., 2017).

Nembhard and Edmondson (2006) described three facets of inclusive leadership as leaders' openness, accessibility, and availability are exhibited to their followers. It means that these three aspects are the key characteristics of leaders to communicate and receive employee's ideas (Carmeli et al., 2010). Inclusive leaders are not only willing to listen and support the followers, but also enable them to encourage employees to say their expectations and discuss alternative approaches to achieve better results. These aspects enable leaders to develop reliable relationships with 
employees. Inclusive relationship directly impacts on employee well-being. Therefore, we propose the following hypothesis:

$\mathrm{H}_{1}$ : Inclusive leadership is positively related to employee well-being

\section{Inclusive Leadership and Personal-job Fit}

According to Shin (2004), person-job fit can be described as "the perceived degree of harmonizing between one's knowledge, skills, abilities, needs, values, and the requirements of specific jobs or job tasks." It is said to be a good person-job fit when an individual appears to perform a job with compatible abilities (KristofBrown et al., 2002). Person-job fit is separated into two sub-types (Edwards, 1991). One form is a demand-ability fit meaning the matching of employees' knowledge, skills, abilities, and the job's requirements. Meanwhile, the other is the needsupply or supply-value fit, indicating employees' needs, desires, and preferences achieved by their job performance (Kristof-Brown et al., 2005).

Three potential ways indicate the relationship between inclusive leadership and person-job fit. Firstly, according to Choi et al. (2015), openness is the characteristic of an inclusive leader. It may help employees reduce the feeling of uncertainty and ambiguity of their roles (Thomas \& Lankau, 2009). Therefore, capabilities are enhanced to meet job requirements. Next, a supportive work climate could be built through inclusive leadership that strengthens the belief of the compatible between their abilities and job requirement (Hollander, 2009; Tims et al., 2011). It means that employees can be motivated as well as experience less aversive arousal due to failure or hardship in a supportive working environment. Babakus et al. (2011) demonstrate that motivation coming from a supportive climate promotes employees' person-job fit. Finally, the inclusive leader tends to provide their employees with expertise experiences through their constant support (Bandura, 1977). In addition, Tims et al. (2011) propose that mastery experiences significantly enhance employees' confidence in their abilities because of positive feedback about their performance. Specifically, inclusive leadership heightens the perception of person-job fit from employees. Therefore, the second hypothesis is proposed:

$\mathrm{H}_{2}$ : Inclusive leadership is positively related to person-job fit

\section{Inclusive Leadership and Innovative Behaviour}

Farr and Ford (1990) described innovative behavior as "the intentional introduction within one's work role of new and useful ideas, processes, products, or procedures." It included a multi-stage process of recognising the problem, 
generating ideas, supporting ideas, and implementing ideas (Kanter, 1988; Scott \& Bruce, 1994). Amabile (1988) considers innovative behaviour as an issue of motivation, while it is also pointed out facilitating by many factors from individuals, groups, and organisations (Anderson et al., 2004). Moreover, each leadership style has a different impact on innovative employee behaviour such as the relation of innovative behaviour with ethical leadership (Yidong \& Xinxin, 2013); and transformational leadership (Sharifirad, 2013; Afsar et al., 2014; Afsar et al., 2015). Those relations have one common characteristic that the leader has to encourage, foster, and support the creativity of their employees resulting in innovative behaviour (Shalley \& Gilson, 2004). Moreover, Rawung et al. (2015) found that a leadership style had a positive effect on knowledge sharing.

Like previous studies, the three aspects of inclusive leadership: openness, accessibility, and availability not only promote the satisfaction of employees in interactions with their leader but also enhance their knowledge and expertise (Carmeli et al., 2010; Choi et al., 2015). Hence, they are likely to involve more in innovative work. The relationship between inclusive leadership and employee's innovative behaviour is positively related in three ways. Firstly, it is the leader's supportive behaviour to motivate their employee's engagement in innovative work because they receive emotional and cognitive resources (Vinarski-Peretz \& Carmeli, 2011). Open interactions, support, encouragement of the leader boost followers' creativity (Tierney et al., 1999), which is a primary factor of innovative behaviour (West, 2002). Secondly, employees are encouraged to give out their novel ideas and suggestions contributing to the foundation of perception of support for employees' creativity (Cerne et al., 2013) and to express their ideas and true thoughts in a supportive working climate as well as to come up with unconventional or contradictory thoughts without feeling insecure or afraid (Avolio et al., 2004). The working climate is improved over time throughout facilitating and fostering innovative behaviour by a leader's support (Åmo, 2006; Cropanzano, 2005). Lastly, inclusive leaders with the features of availability and accessibility enable to explore and evaluate employee performance and innovative behavior. Therefore, we propose the following hypothesis:

$\mathrm{H}_{3}$ : Inclusive leadership is positively related to innovative employee behaviour

\section{Employee Well-being and Mutual Recognition Respect}

Recognition respect is defined as one fundamental characteristic as a human being, which conveys the idea owned by individuals coming from the virtue of their intrinsic worth or dignity. It is also linked to moral reasons. Benditt (2008) 
proposes that person respect means giving persons appropriate consideration for deciding what to do. Mutuality involves a shared sense of relationship, transcending the exchange of benefits immediately and reciprocally (Genero et al., 1992). Partners in the mutual relationship are willing to influence and participate in the bidirectional movement of feelings, thinking, and activities; thereby, it is a shared acceptance of deeply held. In other words, the mutual quality of relationships has a positive impact on psychological growth associating with coping, self-disclosure, sense of self-worth and self-validation, and social ties.

The significance of mutuality is theoretically and empirically supported in studies of interdependence (Rusbult \& Van Lange, 2003), and mutual responsiveness theory (Murray \& Holmes, 2009). Besides, mutuality is proposed to be relatively related to positive psychological as well as health outcomes (Coyne \& Bolger, 1990; Coan et al., 2013; Schumacher et al., 2008). Mutuality is also associated with a reduction in self-regulatory activity (Coan et al., 2013). To sum up, although previous findings show the association between respect with valued attitudes and behaviours, respect is differently conceptualised in several ways. It becomes too important to deeper understand the causal mechanisms such as different forms of respect resulting in different outcomes.

People's feedback and interaction are features that derive self or self-concept, which is posited in theories of self-control and self-evaluation. Positive evaluations of acceptance which can trigger a sense of pleasure in employees have a significant influence on creating a healthy social identity; thereby, they generate a strong correlation with feelings of self-worth and self-esteem (Smith et al., 1998). In other words, the better feelings of self-esteem and self-worth, the better psychology at work improves employee well-being. Moreover, as persons admit recognition respect, this conveys acceptance and inclusion based on the fundamental of a person's dignity (Renger \& Simon, 2011). This meets a person's basic need for inclusion inside social groups as well as advocates persons' demand for affiliation that they originate relationships (Shapiro, 2010). Baumeister and Tice (1990) found that acceptance and inclusion are primary in developing an individual's self-esteem. In general, mutuality turns out to be essential because self-construal rules are situated with the relational schema that can change and rely upon prior experiences with specific people (Baldwin et al., 1990). When individuals communicate recognition respect, their sense of self-worth is likely to be strengthened (Honneth, 1995). Furthermore, in another study of (Clarke \& Mahadi, 2017), they found that mutual recognition respect was positively associated with employee well-being. Therefore, the following hypothesis is proposed:

$\mathrm{H}_{4}$ : Employee well-being is positively related to mutual recognition respect 


\section{Mutual Recognition Respect and Job Performance}

According to the "person-person" fit model of Sagie et al. (1996), the matching values between supervisor and subordinator is critically more significant than that of "person-organisation." Benditt (2008) prompts recognition respect as a fundamental moral value. According to Jung and Avolio (2000), subordinate job performance is attributable to the supervisor-subordinate values congruence, which highlights the supervisor-subordinate reciprocal relationships and influence of their mutual recognition respect on the job performance of subordinates. Furthermore, Markham et al. (2010) examine the leader-member exchange (LMX) fit and find that the linkage between LMX and job performance works mainly at the between dyads level. "In other words, the LMX-performance relationship is dyadic and not group-based." Hence, we can support that mutuality recognition respect is positively associated with employee job performance.

Relational identity theory supports a positive impact of mutual recognition respect on employee job performance (Shapiro, 2010). It emphasises the association degree between members of a group or a relationship, which is based on their needs for affiliation and autonomy. Based on the social exchange theory, Blau (2017) showed that an enhance in job performance provided the recognition respect; it derived a positive relational identity when followers would reciprocate the benefits. In turn, leaders will offer more support and resources to employees to boost employee performance. This happens because of partly experiencing a highquality relationship (Brickson, 2000). Particularly, in an empirical study, Clarke and Mahadi (2017) provided evidence to support the positive relationship between mutual recognition respect and employee job performance. Therefore, we propose the following hypothesis:

$\mathrm{H}_{5}$ : Mutual recognition respect is positively related to employee job performance

\section{Employee Well-being and Job Performance}

Previous studies indicate that there is a positive relationship between employee well-being and job performance (Lyubomirsky et al., 2005). Wright (2014) shows that "emotion-based employee well-being is attained by an employee when s/he experiences psychological well-being in the form of lack of stress and emotional burnout, and positive affectivity." It is also pointed out that emotionbased employee well-being is likely to have a positive relation to job performance (Wright \& Cropanzano, 2000b; Wright, 2014). Additionally, positive affectivity described as the state of being enthusiastic, active, and alert of an employee, is a 
predictor of willingness to solve conflicts, optimism, creativity, and organisational commitment (Choi \& Lee, 2014). Therefore, we propose the following hypothesis:

$\mathrm{H}_{6}$ : Employee well-being is positively related to employee job performance

\section{Person-Job Fit and Employee Well-being and Performance}

Person-job fit is related to employee well-being and job performance in the following ways. First, employees are said to be more inclined to feel a sense of contentment at work when they hold a positive attitude towards a person-job fit. Quinn (2005) claimed that those employees who well perceive that requirements of the job are compatible with their abilities often feel more fulfilled in their work. According to Brkich et al. (2002) and Singh and Greenhaus (2004), the more employees feel that their abilities are properly matched with the job demands, the more they are satisfied. Second, a good match of employees' skills and work requirements results in less stress and exhaustion (Singh \& Greenhaus, 2004) and less worry (Quinn, 2005). In other words, fatigue at work can be diminished under the influence of positive perception of person-job fit (Halbesleben \& Buckley, 2004; Janssen, 2004; Wright \& Hobfoll, 2004). As a result, it enhances their wellbeing at work.

Finally, positive perception of employees' capabilities acts as their resources which are regarded as significant stimulators to task accomplishment and personal growth; thus, enhance the performance at work (Akkermans et al., 2013; Xanthopoulou et al., 2009). Brkich et al. (2002) clarified that the match between employees' capabilities and job demands helps manage tasks more effectively (Hamid \& Yahya, 2011), which accordingly, fosters their job performance. When the employee's ability and the complexity of the job do not fit, this can lead to poor job performance. In an empirical study, Lin et al. (2014) provided evidence to support the positive relationship between person-job fit and employee job performance. Therefore, two hypotheses are proposed:

$\mathrm{H}_{7}$ : Person-job fit is positively related to employee well-being

$\mathrm{H}_{8}$ : Person-job fit is positively related to job performance

\section{Person-Job Fit and Innovative Behaviour}

When employees self-evaluate themselves for being qualified for the job, they form a sense of contentment, achievement, and confidence (Xie \& Johns, 1995). Cerne et al. (2013) propose that these positive emotions encourage them to be 
highly devoted and committed to the job, foster supportive ideas for innovative development, and repress fear for failures. Also, Choi et al. (2017) argued that person-job fit perception positively affects their projected results of the new trials and experiments. Consequently, motivation to initiate new things, ideas, and processes are triggered by positive expectations (Cerne et al., 2013).

Moreover, positive self-evaluation of employees' abilities to meet the job requirements stimulates flexibility and creativity in thinking, which is one essential feature of innovative behaviour. The employees' thoughts are more flexible and creative as a result of the less pressure at work since they have confidence in their abilities (Avolio et al., 2004). Therefore, we propose the following hypothesis:

$\mathrm{H}_{9}$ : Person-job fit is positively related to innovative behaviour

\section{Innovative Behaviour and Job Performance}

Innovative behaviour in a workplace setting is regarded as the intention of the employee to introduce or implement new ideas, products, and processes in terms of work role, team, or organisation (Yuan \& Woodman, 2010). Innovative behaviour of employees consists of discovering new technologies, introducing new techniques to meet goals, practicing new task approaches, and investigating resources for generating new ideas (Janssen, 2000; Yuan \& Woodman, 2010). Employees' willingness to learn, explore, and initiate ideas results in resolution of pressing problems; consequently, triggering higher job performance (Amabile et al., 2005). It plays a vital role in job performance when employees are motivated to acquire new information during the learning process to augment their performance (Walumbwa et al., 2009). Therefore, hypothesis 10 is developed:

\section{$\mathrm{H}_{10}$ : Innovative behaviour is positively related to job performance}

\section{Intrinsic Motivation and Employee Well-being}

Self-determination theory stated by Niemiec et al. (2010) claims that people are innately excited to explore and learn, to practice and enhance their capabilities and to accept challenges. According to Ryan and Deci (2000a), intrinsic motivation refers to the doing of an activity for its inherent satisfactions rather than for some separable consequences. Intrinsically motivated employees perform a task solely for the inherent interest, excitement, and pleasure entailed in the task rather than for external rewards or pressures. Enjoyment is claimed to have a positive association with behavioral measures of intrinsic motivation (Harackiewicz, 1979). Reeve et al. (1986) found that experience was excitement in relation to intrinsically motivated 
activities. The combined measures of interest, pleasure, fun, and enjoyment are taken to assess intrinsic motivation levels (Guay et al., 2000).

Intrinsic motivation is considered valuable in workplace studies for its remarkable impacts on a wide range of on-the-job behaviours. Employees' intrinsic motivation is shown to be positively associated with their behaviours of organisational relationships (Alge et al., 2006), employee creativity (Zhang \& Bartol, 2010), and work performance (Kuvaas et al., 2017). Employees' intrinsic motivation is suggested to be a partial mediator in the relationship between their perceptions of procedural justice and task performance (Zapata-Phelan et al., 2009).

Niemiec et al. (2010) claim that people are innately excited to explore and learn, to practice and enhance their capabilities and to accept challenges. According to Ryan and Deci (2000a), intrinsic motivation refers to the doing of an activity for its inherent satisfactions rather than for some separable consequences. Intrinsically motivated employees perform a task solely for the inherent interest, excitement, and pleasure entailed in the task rather than for external rewards or pressures. Enjoyment is claimed to have a positive association with behavioral measures of intrinsic motivation (Harackiewicz, 1979). Reeve et al. (1986) found that experience was excitement in relation to intrinsically motivated activities. The combined measures of interest, pleasure, fun, and enjoyment are taken to assess intrinsic motivation levels (Guay et al., 2000).

$\mathrm{H}_{11}$ : Employee well-being is positively related to intrinsic motivation

\section{Intrinsic Motivation and Job Performance}

Individual job performance is regarded as the most important outcome of motivation. Intrinsic motivation is claimed to positively result in several jobrelated outcome such as enthusiasm and engagement (Van den Broeck et al., 2013), thriving (Spreitzer et al., 2005), employee well-being (Nix et al., 1999), and job performance (Kuvaas et al., 2017). These positive states are theorised to invigorate and to stimulate employees to be more attentive to their work (Kuvaas et al., 2017). Apart from positive influences on performance in school, work and physical aspects (Cerasoli et al., 2014), intrinsic motivation is shown to be positively associated with contextual work performance and creativity (Gagné \& Deci, 2005). Therefore, we propose the following hypothesis:

$\mathrm{H}_{12}$ : Intrinsic motivation is positively related to job performance

Figure 1 illustrates the research model with hypothesis development: 


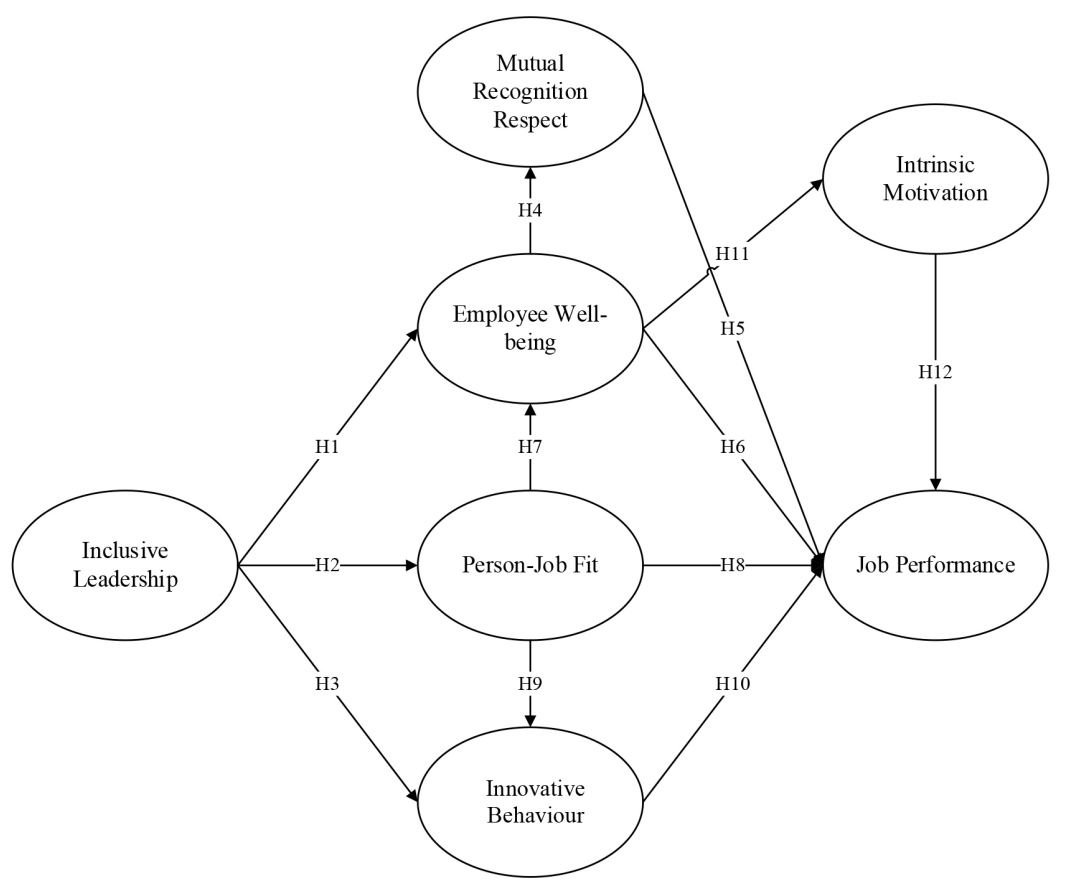

Figure 1. The research model

\section{METHODOLOGY}

In this study, we use a back-translation procedure as the method for conducting the questionnaire design. The initial English version was translated into Vietnamese with some adjustments to fit the Vietnamese context and then back-translated into the original language. The procedure continued until the two versions of the measurement scale were compatible with meaning. The measurement of all variables was based on a 5-point Likert-type scale, ranging from 1 (Strongly Disagree) to 5 (Strongly Agree).

\section{Measurement}

First, six items of inclusive leadership variable were adapted from Choi et al. (2017) to assess three dimensions of inclusive leaders: openness, availability, and accessibility with two items representing each dimension. Sample items for openness dimension were "My manager is attentive to new opportunities to improve work processes" and "My manager is open to discuss the desired goals and new ways to achieve them." Secondly, three items were adapted from Mulki 
et al. (2006) and Choi et al. (2017) to measure person-job fit. The items were: (1) My skills and abilities perfectly match with my job demands; (2) My personal likes and dislikes match perfectly with my job demands; and (3) There is a good fit between my job and me. Mulki et al. (2006) clarified that the person-job fit is positively associated with participate leadership and overall job satisfaction.

Thirdly, five items adapted from Arnold et al. (2007) are used to measure employee well-being asking about the extent to which employees feel motivated, energetic, enthusiastic, lively, and joyful in the past six months. One item on cheerful feeling at work was excluded from the original scale since its meaning bore a similarity to that of being joyful in Vietnamese. Fourthly, the measurement of innovative employee behaviour is self-reported by the respondents. Six items were adapted (Janssen, 2000). Examples of the items were "I search out new working methods, techniques, or instruments" or "I transform innovative ideas into useful applications." Fifthly, mutual recognised respect includes six items that are adapted from (Clarke \& Mahadi, 2017). Sixthly, the four-item intrinsic motivation scale was adapted from Kuvaas et al. (2017), which was first introduced by Kuvaas (2006) and later developed by Kuvaas and Dysvik (2009) to discover the employees' attitude towards their current job. Finally, job performance is assessed by six items using the scale of (Williams \& Anderson, 1991). Examples of the items were "Perform tasks that are expected of him/her" or "Engages in activities that will directly affect his/her performance evaluation." All 36 items were denoted and presented in the appendix.

\section{Questionnaire Design}

The sample size for an exploratory study requires at least 4-5 times the number of items (Malhotra et al., 2006). Specifically, a rule of thumb introduced by Green (1991) to decide on the appropriate number for observations suggests that sample size $=50+(8 \times$ number of measurement items $)$. There are 36 measurement items in our study. Therefore, the minimum sample size should be $50+(8 \times 36)=338$. The questionnaire survey covers three parts: (1) introduction and purpose of the survey; (2) respondents' profile including age, gender, education level, and working position; and (3) 36 questions constructing the hypothetical model.

\section{Data Collection}

The survey questionnaire took four months from February 2018 to May 2018. Data collection includes two phases: a pilot test and an official survey, which is conducted in Ho Chi Minh City, Vietnam. A pilot test with the sample size of 37 face-to-face interviews is used to assess whether the designed measurement 
scale was transparent enough not to cause any confusion and easy to evaluate or not. After taking feedback on the questionnaire, slight adjustments were made to complete the Vietnamese official survey.

There are about 1748 interior design and construction companies in Ho Chi Minh City, Vietnam (Yellow Pages Vietnam, 2019). These numbers include many companies stopping doing business or going bankrupt. We could not access the real number of existing companies. Therefore, a snowball sampling method is applied in this study as it is a non-probability sampling method and helps to approach a specific population where random sampling is not possible. With the invaluable supports from 20 company directors, we can contact 120 interior design and construction companies to distribute 400 survey questionnaires to their employees. We dropped the questionnaire hard copies at the human resource department and came back to receive the filled forms after two weeks. After eliminating 13 incomplete questionnaires, 387 valid samples are using to test the hypothetical model. This sample size also met the minimum requirement with the response rate of $96.75 \%$, which indicated a high and preferable rate of response (the threshold mentioned above is 338 ).

The demographic information showed a relative gender balance. There are 204 male respondents, who account for $52.7 \%$ of the total number whereas the remaining 183 female respondents represent $47.3 \%$. The majority of employees are in the young working-age group ranging from 20 to 40 years old, taking up $95.4 \%$. Moreover, $74.6 \%$ of the respondents hold a bachelor's degree or master's degree. Meanwhile, $25.4 \%$ of them acquired higher academic qualifications.

\section{RESULTS}

\section{Reliability Analysis}

To analyse the reliability of the hypothetical model, we calculate Cronbach's alpha coefficients and exploratory factor analysis (EFA) using SPSS 20.0 software. According to Kline (1998), the Cronbach's alpha coefficients of around 0.9 is considered as excellent, around 0.8 as very good, from 0.6 to 0.7 as adequate and below 0.5 as unreliable. The Cronbach's alpha indicators vary from 0.771 to 0.902 showing good internal reliability of the construct measures. In addition, KMO Barlett's Test coefficient is required to be over 0.5 with the sig. $<0.05$ and total variance explained $>50 \%$. The requirement for factor loadings is at least 0.5 . As a result, five items (IL1, IB1, IB2, IM3, and IP1) are eliminated because of inadequate factor loadings. Table 1 presented the testing results of EFA. 


\section{Confirmation Factor Analysis}

The validity of a measurement model is based on factor loadings through conducting Confirmation Factor Analysis (CFA) conducted by AMOS 20.0 software. In addition, the recommended level for indices of composite reliability (CR) is at least 0.7, and average variance extracted (AVE) is larger than 0.5 (Hair et al., 1998). Table 1 reported the findings of CFA. All indices of CR and AVE satisfy the minimum criteria.

Table 1

Test of EFA and CFA

\begin{tabular}{|c|c|c|c|c|c|}
\hline Variables & Items & EFA & $\mathrm{CA}$ & $\mathrm{CR}$ & AVE \\
\hline \multirow[t]{5}{*}{ IL } & IL2 & 0.610 & 0.838 & 0.838 & 0.510 \\
\hline & IL3 & 0.644 & & & \\
\hline & IL4 & 0.730 & & & \\
\hline & IL5 & 0.764 & & & \\
\hline & IL6 & 0.730 & & & \\
\hline \multirow[t]{3}{*}{ PJF } & PJF1 & 0.725 & 0.808 & 0.816 & 0.598 \\
\hline & PJF2 & 0.854 & & & \\
\hline & PJF3 & 0.745 & & & \\
\hline \multirow[t]{5}{*}{ EWB } & EWB1 & 0.791 & 0.902 & 0.902 & 0.649 \\
\hline & EWB2 & 0.823 & & & \\
\hline & EWB3 & 0.773 & & & \\
\hline & EWB4 & 0.707 & & & \\
\hline & EWB5 & 0.737 & & & \\
\hline \multirow[t]{4}{*}{ IB } & IB3 & 0.574 & 0.849 & 0.850 & 0.587 \\
\hline & IB4 & 0.725 & & & \\
\hline & IB5 & 0.752 & & & \\
\hline & IB6 & 0.713 & & & \\
\hline \multirow[t]{6}{*}{ MR } & MR1 & 0.609 & 0.872 & 0.873 & 0.579 \\
\hline & MR2 & 0.663 & & & \\
\hline & MR3 & 0.753 & & & \\
\hline & MR4 & 0.721 & & & \\
\hline & MR5 & 0.686 & & & \\
\hline & MR6 & 0.597 & & & \\
\hline
\end{tabular}


Table 1: (continued)

\begin{tabular}{llllll}
\hline Variables & Items & EFA & CA & CR & AVE \\
\hline IM & IM1 & 0.517 & 0.771 & 0.775 & 0.536 \\
& IM2 & 0.526 & & & \\
& IM4 & 0.699 & & & \\
JP & JP2 & 0.664 & 0.852 & 0.853 & 0.539 \\
& JP3 & 0.707 & & & \\
& JP4 & 0.734 & & & \\
& JP5 & 0.632 & & & \\
& JP6 & 0.669 & & & \\
\hline
\end{tabular}

Notes: IL = inclusive leadership; PJF = person-job fit; EWB = employee well-being; IB = innovative behaviour; $\mathrm{MR}=$ mutual recognition respect; $\mathrm{IM}=$ intrinsic motivation; $\mathrm{JP}=$ job performance .

Table 2

Testing the model fit

\begin{tabular}{lll}
\hline Model fit indices & Recommended acceptable level & Indices value \\
\hline X2/df & 1 to 3 & 2.331 \\
RMSEA & $<0.08$ & 0.059 \\
GFI & $>0.90$ & 0.857 \\
AGFI & $>=0.80$ & 0.827 \\
IFI & $>=0.90$ & 0.922 \\
CFI & $>=0.90$ & 0.922 \\
PGFI & $>0.50$ & 0.708 \\
PNFI & $>0.50$ & 0.769 \\
\hline
\end{tabular}

The analysis of fitness of structural model indicates the statistical significance of proposed hypotheses. Recommended standards including normal chi-square (X2/ df) is from 1 to 3, goodness-of-fit index (GFI); incremental fit index (IFI); normed fit index (NFI); Tucker-Lewis index (TLI); and comparative fit index (CFI) is at least 0.8; and root mean square error of approximation (RMSEA) is from 0 to 0.08 (Byrne, 2016). The findings from CFA illustrated that the model fit indices $(\mathrm{X} 2 / \mathrm{df}=2.331 ; \mathrm{p}<0.000 ; \mathrm{GFI}=0.857$; IFI $=0.922$; RMSEA $=0.059 ; \mathrm{NFI}$ $=0.871$; TLI $=0.911$; and CFI $=0.922)$ demonstrate the acceptable validity of measurement model. Table 2 illustrated the testing results of the model fit. 


\section{Structural Equation Modeling and Hypothesis Testing}

Table 3 illustrates that almost all of the estimated coefficients are statistically significant, except for the effect of employee well-being and person-job fit on job performance (rejecting $\mathrm{H}_{6}, \mathrm{H}_{8}$ ). The coefficients of inclusive leadership to employee well-being, person-job fit, and innovative behaviour are $0.601,0.705$, and 0.558 , respectively. It means that $\mathrm{H}_{1}, \mathrm{H}_{2}, \mathrm{H}_{3}$ are strongly supported, in which the relation of inclusive leadership and person-job fit has the most critical interrelation. The results also indicated that employee well-being has a considerable impact on both mutual recognition respect and intrinsic motivation with the corresponding coefficients being 0.460 and 0.697 , respectively, supporting $\mathrm{H}_{4}, \mathrm{H}_{11}$. Mutual recognition respect, innovative behaviour, intrinsic motivation are three variables directly related to job performance with the estimated coefficients of $0.305,0.258$, and 0.224 , respectively, supporting $\mathrm{H}_{5}, \mathrm{H}_{10}, \mathrm{H}_{12}$. Lastly, the effects of person-job fit on employee well-being and innovative behaviour are positively significant, with the path coefficient of the former being 0.323 and of the latter being 0.120 , supporting $\mathrm{H}_{7}, \mathrm{H}_{9}$.

Table 3

Hypothesis testing results

\begin{tabular}{lllllll}
\hline Hypothesis & Estimate & S.E. & C.R. & P & Result \\
\hline $\mathrm{H}_{1}$ & $\begin{array}{l}\text { Inclusive leadership is positively } \\
\text { related to employee well-being }\end{array}$ & 0.601 & 0.085 & 7.04 & ${ }^{* * *}$ & Accepted \\
$\mathrm{H}_{2} \quad \begin{array}{l}\text { Inclusive leadership is positively } \\
\text { related to person-job fit }\end{array}$ & 0.705 & 0.083 & 8.54 & ${ }^{* * *}$ & Accepted \\
$\mathrm{H}_{3} \quad \begin{array}{l}\text { Inclusive leadership is positively } \\
\text { related to innovative behavior }\end{array}$ & 0.558 & 0.074 & 7.54 & ${ }^{* * *}$ & Accepted \\
$\mathrm{H}_{4} \quad \begin{array}{l}\text { Employee well-being is positively } \\
\text { related to mutual recognition respect }\end{array}$ & 0.460 & 0.043 & 10.59 & ${ }^{* * *}$ & Accepted \\
$\mathrm{H}_{5} \quad \begin{array}{l}\text { Mutual recognition respect is } \\
\text { positively related job performance }\end{array}$ & 0.305 & 0.057 & 5.31 & $* * * *$ & Accepted \\
$\mathrm{H}_{6} \quad \begin{array}{l}\text { Employee well-being is positively } \\
\text { related to job performance }\end{array}$ & -0.057 & 0.064 & -0.89 & 0.376 & Rejected \\
$\mathrm{H}_{7} \quad \begin{array}{l}\text { Person-job fit is positively related to } \\
\text { employee well-being }\end{array}$ & 0.323 & 0.064 & 5.03 & $* * * *$ & Accepted \\
$\mathrm{H}_{8} \quad \begin{array}{l}\text { Person-job fit is positively related to } \\
\text { job performance }\end{array}$ & 0.058 & 0.038 & 1.52 & 0.129 & Rejected \\
$\mathrm{H}_{9} \quad \begin{array}{l}\text { Person-job fit is positively related to } \\
\text { innovative behavior }\end{array}$ & 0.120 & 0.052 & 2.33 & 0.02 & Accepted \\
\hline
\end{tabular}


Table 3: (continued)

\begin{tabular}{|c|c|c|c|c|c|c|}
\hline \multicolumn{2}{|c|}{ Hypothesis } & \multirow{2}{*}{$\begin{array}{l}\text { Estimate } \\
0.258\end{array}$} & \multirow{2}{*}{$\frac{\text { S.E. }}{0.047}$} & \multirow{2}{*}{$\begin{array}{l}\text { C.R. } \\
5.54\end{array}$} & \multirow{2}{*}{$\frac{\mathrm{P}}{* * *}$} & \multirow{2}{*}{$\begin{array}{l}\text { Result } \\
\text { Accepted }\end{array}$} \\
\hline $\mathrm{H}_{10}$ & $\begin{array}{l}\text { Innovative behavior is positively } \\
\text { related to job performance }\end{array}$ & & & & & \\
\hline $\mathrm{H}_{11}$ & $\begin{array}{l}\text { Employee well-being is positively } \\
\text { related to intrinsic motivation }\end{array}$ & 0.697 & 0.053 & 13.15 & $* * *$ & Accepted \\
\hline $\mathrm{H}_{12}$ & $\begin{array}{l}\text { Intrinsic motivation is positively } \\
\text { related to job performance }\end{array}$ & 0.224 & 0.061 & 3.65 & $* * *$ & Accepted \\
\hline
\end{tabular}

Notes: ${ }^{*} p$-value $<0.05 ;{ }^{* *} p$-value $<0.01 ;{ }^{* * *} p$-value $<0.001$

\section{The Test of Mediating Effects}

This study decides to adopt the three-step method by Baron and Kenny (1986) to provide a deeper understanding of the mediating effects. As can be seen from Table 4, mutual respect recognition and intrinsic motivation both have a partial mediating effect on the relationship between employee well-being and job performance. In addition, innovative behaviour has partially mediated the effect of person-job fit on job performance. The mediating roles of mutual recognition respect, intrinsic motivation, and innovative behaviour are found to be statistically significant, confirming the proposed hypotheses.

Table 4

Results of testing the mediating effect (coefficient in regressions)

\begin{tabular}{llllllll}
\hline IV & M & DV & IV--> DV & IV--> M & \multicolumn{2}{l}{ IV+M --> DV } & Mediating \\
\hline & & & & & IV--> DV & M--> DV & \\
\hline EWB & MR & JP & -0.47 & $0.454^{* * *}$ & $0.141^{* * *}$ & $0.312^{* * *}$ & Partial \\
EWB & IM & JP & -0.47 & $0.697^{* * *}$ & $0.152^{* * *}$ & $0.219^{* *}$ & Partial \\
PJF & IB & JP & 0.5 & $0.121^{*}$ & $0.03^{* * *}$ & $0.258^{* * *}$ & Partial \\
\hline
\end{tabular}

Notes $1:{ }^{*} p$-value $<0.05 ;{ }^{* *} p$-value $<0.01 ;{ }^{* * *} p$-value $<0.001$.

Note 2: IV = Independent variable; $\mathrm{M}=$ Mediator, $\mathrm{DV}=$ Dependent variable; $\mathrm{EWB}=$ Employee well-being; $\mathrm{MR}$ $=$ Mutual recognition respect; $\mathrm{IM}=$ Intrinsic motivation; $\mathrm{JP}=$ Job performance.

Note 3: Baron and Kenny (1986)'s three-step approach for analysis of mediating effects is conducted as follows: Step 1: IVàDV is significant.

Step 2: IVàM is significant.

Step 3: IV+MàDV.

1) When $M$ is significant, but $I V$ is not significant, $M$ has a full mediating effect.

2) When both $M$ and $I V$ are significant, $M$ has a partial mediating effect. 


\section{DISCUSSION}

\section{Theoretical Contributions}

Consistent with previous studies, this paper shows that inclusive leadership has a positive influence on employee well-being (Arnold et al., 2007; Choi et al., 2017; Sharifirad, 2013), person-job fit (Gong et al., 2009; Thomas \& Lankau, 2009; Tims et al., 2011), and innovative behaviour (Shuck \& Herd, 2012). The existing study proposed that positive behaviour from a particular type of leadership which had an inspirational effect on employees might foster employee well-being and person-job fit (Babakus et al., 2011; Sharifirad, 2013). Most of previous leadership research in association with employee well-being and person-job fit emphasise general leadership style (Carmeli et al., 2010; Tierney et al., 1999) or specifically, transformational leadership (Sharifirad, 2013) and servant leadership (Babakus et al., 2011) in which employees are motivated by internalising and prioritising a larger collective cause over individual interests (Lian \& Tui, 2012). Nevertheless, our study focused on inclusive leadership as one underexplored facet of relational leadership, which centers employees' needs to enhance their well-being and person-job fit (Hollander, 2009). Besides, the characteristics of inclusive leaders are considered essential for triggering employees' engagement in generating innovation, especially in a knowledge-intensive, complicated and creative environment like the interior design industry in Vietnam (Carmeli et al., 2010). Leaders' supportive behavior fuels employees' commitment to contributing to the innovating process (Cerne et al., 2013; Choi et al., 2017; Vinarski-Peretz \& Carmeli, 2011), which, in turn, have a positive impact on job performance. This finding is aligned with previous research (Amabile et al., 2005; Walumbwa et al., 2009).

The relationship between inclusive leadership and its effects are reassured about the Vietnamese workplace context. Choi et al. (2017) find that "leadership and its outcomes are highly culturally dependent." Distinct from the contexts in the United States and Europe, Vietnam and other Asian countries have a cultural tendency towards such characteristics as high collectivism, long-term oriented culture, and high uncertainty avoidance (Hofstede, 2001; Wang \& Yi, 2011). Collectivistic cultures, for example, attach great importance to group and unity within the social group. In collectivistic cultures, leaders and employees prioritise coordinating to form a strongly cohesive working environment; meanwhile, each employee tends to be more self-centered in individualistic cultures (Hofstede, 2001). Therefore, the role of inclusive leaders is substantial in this context in correlation with employee well-being, person-job fit, and innovative behaviour since an inspiring workplace 
is created with such supportive aspects as availability, openness, and accessibility from the leaders.

Previous studies demonstrated the positive linkage between employee well-being and person-job fit and job performance (Wright \& Cropanzano, 2000a; Wright, 2014). Conversely, in this study, no direct relationship is found between the two predictors and job performance. Discrepancies in different contexts might explain this contradiction. Interestingly, these findings stimulate us to discover the role of mutual recognition, respect, and intrinsic motivation as motivators in the relationship between employee well-being and job performance. Our study strengthens theory on the effect of employee well-being on recognition type of respect (Renger \& Simon, 2011; Shapiro, 2010) which, in turn, enhances job performance in a different context that (Clarke \& Mahadi, 2017) have developed. Likewise, in alignment with previous studies, employee well-being acts as a significant driver of intrinsic motivation which, consequently, has a positive influence on job performance (Kuvaas et al., 2017; Ryan \& Deci, 2000b; Van den Broeck et al., 2013).

It is worth noting that we identified the mediating role of innovative behaviour in the relationship between person-job fit and job performance. Our study found that person-job fit is statistically significant in correlation with innovative behavior (Avolio et al., 2004; Cerne et al., 2013; Choi et al., 2017) and job performance (Akkermans et al., 2013; Hamid \& Yahya, 2011; Xanthopoulou et al., 2009). Consistent with the study of Amabile et al. (2005), our result confirms the positive linkage between innovative behaviour and job performance. In such an intensively demanding industry such as interior design and construction, the priorities in job performance is employees' ability to recognise the problem, generate creative solutions, and implement them. Before doing so, an employee must acquire a predefined ability that is compatible with job demands.

The findings extend the existing literature in several ways. First, the results confirm the vital role of inclusive leadership in creating a motivational workplace where employee well-being, person-job fit, and innovative behaviour are encouraged in the context of Vietnamese interior design and construction companies. Second, though employee well-being and person-job fit, surprisingly, have no relationship to job performance, the result opens a new path for investigating the underlying mechanisms. We discover recognition respect and intrinsic motivation as two potential mediators in the linkage between employee well-being and job performance. Also, innovative behaviour is found to play a mediating role in the linkage between person-job fit and job performance. We call for future research to test the significance of these newly explored mediators in the relationship 
between different aspects of a motivating workplace to enhance overall job performance. Finally, our study is up-to-date in response to the call for further research into mutual recognition respect's effects on job-related outcomes in other cultural contexts (Clarke \& Mahadi, 2017). We clarify the significance of mutual recognition respect in association with job performance in the context of Vietnam. Considering the few studies that have thoroughly investigated this dimension of respect despite its fundamental moral value (Benditt, 2008), more attention should be paid on studying mutual recognition respect in the future.

The three-step approach for testing the mediating effect by Baron and Kenny (1986) may be out-of-date and raised for further discussions. Future research must take this limitation into careful consideration. We encourage various updated approaches for mediation testing to ensure the validity of the result. Besides, concerning the distinctive characteristics of a young but intensively demanding industry of interior design and construction in Vietnam, differences in terms of cultural contexts and characteristics of the industry are inevitable.

\section{Managerial Implications}

Our results reassure the role of inclusive leadership as a substantial stimulator of employee well-being, person-job fit, and innovative behaviour. Therefore, leaders should thoroughly consider their human resource approaches to make a constructive contribution to shaping an inspiring workplace where employees feel motivated to devote. Supportive behaviour of supervisors such as being available, willing to listen, and appreciative of their subordinates' voice of concerns and ideas would make them engrossed in tackling assigned tasks. Moreover, the provision of training programs, assessment of job performance, feedback, and rewards are advisable applications in which job resources are prioritised to achieve high employee well-being, person-job fit, and innovative behaviour (Choi et al., 2015; Hamid \& Yahya, 2011).

The mediating role of innovative behaviour, mutual recognition respect, and intrinsic motivation must be emphasised to achieve greater performance. In an environment where employees can experience a positive emotional state, they are more likely to be intrinsically motivated and express mutual recognition respect for one another and receive the same thing in return. Decentralisation in decisionmaking, leadership practices of listening, understanding employees' viewpoints, inviting them to self-reflect and verbal praise are encouraged to increase intrinsic motivation. Mutual recognition respect can be gained by constructive feedbacks, communication, evaluation process in which individuals' feelings of self-esteem and self-worth are prioritised. Moreover, recruitment process where employees' 
potentials are sought to be qualified for the job demands and on-the-job training is vital as person-job fit would give employees more advantages in producing innovative behaviours and direct them for immediate adjustments, which results in developing appropriate characteristics for the job (Singh \& Greenhaus, 2004). Consequently, cultivating employees' confidence in generating ideas would arouse high-quality job outcomes.

\section{CONCLUSION}

The emphasis of this study is put on inclusive leadership in its relationship with employee well-being, person-job fit, and innovative behaviour and how these factors work to enhance job performance. The results confirm inclusive leadership as a strong motivator of the three above-mentioned factors. Employee well-being and person-job fit, inconsistent with previous studies, surprisingly show no direct impact on job performance. The findings brought to light the mediating role of mutual recognition respect, intrinsic motivation, and innovative behaviour, adding to the existing literature in terms of examining job-related relationships in the Vietnamese context.

Furthermore, practical human resource approaches are introduced to achieve desired outcomes. Particularly, our findings theoretically and empirically contribute to managerial implications in terms of job performance by enhancing inclusive leadership practices, working motivations, and mutual recognition respect in the workplace. First, leaders should actively show their openness, availability, and accessibility in their interactions with employees to enhance motivational impacts on them. Second, it is important to set up a better working environment that emphasises mutual recognition respect and innovative behaviour, specifically, a workplace where the employees can recognise their sense of self-worth and comfortably share their ideas and thoughts. Based on the results of this study, organisations are recommended to enhance their performance by consistently increasing employee's intrinsic motivation. For instance, periodical feedbacks are particular activities that not only boost their intrinsic motivation but also build up mutual understanding as well as the stable relationship between superiors and subordinators. Last but not least, the indirect impacts of employee well-being and person-job fit on job performance are statistically significant. It is suggested that managers should take into account these two factors to improve the effects of other factors, including mutual recognition respect, intrinsic motivation, and innovative behaviour on job performance. 


\section{Limitations and Future Research}

First, we focused on the number of respondents working in the targeted industry. Perhaps different industries could add more value to the research so that the finding will be generalised. Second, the research model has not explored demographic indicators and different regions in terms of cultural contexts and life styles. Hence, future studies should consider these characteristics.

\section{REFERENCES}

Afsar, B., Badir, Y., \& Khan, M.M. (2015). Person-job fit, person-organization fit and innovative work behavior: The mediating role of innovation trust. Journal of High Technology Management Research, 26(2), 105-116. https://doi.org/10.1016/j. hitech.2015.09.001

Afsar, B., Badir, Y., \& Bin Saeed, B. (2014). Transformational leadership and innovative work behavior. Industrial Management \& Data Systems, 114(8), 1270-1300.

Akkermans, J., Schaufeli, W.B., Brenninkmeijer, V., \& Blonk, R.W.B. (2013). The role of career competencies in the Job Demands-Resources model. Journal of Vocational Behavior, 83(3), 356-366. https://doi.org/10.1016/j.jvb.2013.06.011

Alge, B.J., Ballinger, G.A., Tangirala, S., \& Oakley, J.L. (2006). Information privacy in organizations: Empowering creative and extrarole performance. Journal of Applied Psychology, 91(1), 221.

Amabile, T.M. (1988). A model of creativity and innovation in organizations. Research in Organizational Behavior, 10, 123-167.

Amabile, T.M., Barsade, S.G., Mueller, J.S., \& Staw, B.M. (2005). Affect and creativity at work. Administrative Science Quarterly, 50(3), 367-403. https://doi.org/10.2189/ asqu.2005.50.3.367

Åmo, B.W. (2006). Employee innovation behaviour in health care: The influence from management and colleagues. International Nursing Review, 53(3), 231-237.

Anderson, N., De Dreu, C.K.W., \& Nijstad, B.A. (2004). The routinization of innovation research: A constructively critical review of the state of the science. Journal of Organizational Behavior, 25(2), 147-173.

Arnold, K.A., Turner, N., Barling, J., Kelloway, E.K., \& McKee, M.C. (2007). Transformational leadership and psychological well-being: The mediating role of meaningful work. Journal of Occupational Health Psychology, 12(3), 193-203. https://doi.org/10.1037/1076-8998.12.3.193

Avolio, B.J., Gardner, W.L., Walumbwa, F.O., Luthans, F., \& May, D.R. (2004). Unlocking the mask: A look at the process by which authentic leaders impact follower attitudes and behaviors. The Leadership Quarterly, 15(6), 801-823.

Babakus, E., Yavas, U., \& Ashill, N.J. (2011). Service worker burnout and turnover intentions: Roles of person-job fit, servant leadership, and customer orientation. Services Marketing Quarterly, 32(1), 17-31. https://doi.org/10.1080/15332969.2 011.533091 
Baldwin, M.W., Carrell, S.E., \& Lopez, D.F. (1990). Priming relationship schemas: My advisor and the Pope are watching me from the back of my mind. Journal of Experimental Social Psychology, 26(5), 435-454.

Bandura, A. (1977). Self-efficacy: Toward a unifying theory of behavioral change. Psychological Review, 84(2), 191.

Baron, R.M., \& Kenny, D.A. (1986). The moderator-mediator variable distinction in social psychological research: Conceptual, strategic, and statistical considerations. Journal of Personality and Social Psychology, 51, 1173-1182.

Baumeister, R.F., \& Tice, D.M. (1990). Point-counterpoints: Anxiety and social exclusion. Journal of Social and Clinical Psychology, 9(2), 165.

Benditt, T.M. (2008). Why respect matters. The Journal of Value Inquiry, 42(4), 487-496.

Blau, P. (2017). Exchange and power in social life. New York: Routledge.

Brickson, S. (2000). The impact of identity orientation on individual and organizational outcomes in demographically diverse settings. Academy of Management Review, 25(1), 82-101.

Brkich, M., Jeffs, D., \& Carless, S.A. (2002). A global self-report measure of personjob fit. European Journal of Psychological Assessment, 18, 43-51. https://doi. org/10.1027//1015-5759.18.1.43

Byrne, B.M. (2016). Structural equation modeling with AMOS: Basic concepts, applications, and programming, 3rd ed. New York: Routledge.

Carmeli, A., Reiter-Palmon, R., \& Ziv, E. (2010). Inclusive leadership and employee involvement in creative tasks in the workplace: The mediating role of psychological safety. Creativity Research Journal, 22(3), 250-260. https://doi.org/10.1080/104 00419.2010 .504654

Cartwright, S., \& Holmes, N. (2006). The meaning of work: The challenge of regaining employee engagement and reducing cynicism. Human Resource Management Review, 16(2), 199-208.

Cerasoli, C.P., Nicklin, J.M., \& Ford, M.T. (2014). Intrinsic motivation and extrinsic incentives jointly predict performance: A 40-year meta-analysis. Psychological Bulletin, 140(4), 980.

Cerne, M., Jaklic, M., \& Skerlavaj, M. (2013). Authentic leadership, creativity, and innovation: A multilevel perspective. Leadership, 9(1), 63-85. https://doi. org/10.1177/1742715012455130

Choi, S.B., Tran, T.B.H., \& Kang, S.W. (2017). Inclusive leadership and employee wellbeing: The mediating role of person-job fit. Journal of Happiness Studies, 18(6), 1877-1901. https://doi.org/10.1007/s10902-016-9801-6

Choi, S.B., Tran, T.B.H., \& Park, B.I. (2015). Inclusive leadership and work engagement: Mediating roles of affective organizational commitment and creativity. Social Behavior and Personality: An International Journal, 43(6), 931-943.

Choi, Y., \& Lee, D. (2014). Psychological capital, big five traits, and employee outcomes. Journal of Managerial Psychology, 29(2), 122-140.

Clarke, N., \& Mahadi, N. (2017). Mutual recognition respect between leaders and followers: Its relationship to follower job performance and well-being. Journal of Business Ethics, 141(1), 163-178. https://doi.org/10.1007/s10551-015-2724-z 
Coan, J.A., Kasle, S., Jackson, A., Schaefer, H.S., \& Davidson, R.J. (2013). Mutuality and the social regulation of neural threat responding. Attachment \& Human Development, 15(3), 303-315.

Coyne, J.C., \& Bolger, N. (1990). Doing without social support as an explanatory concept. Journal of Social and Clinical Psychology, 9(1), 148-158.

Cropanzano, R. (2005). Social exchange theory: An interdisciplinary review. Journal of Management, 31(6), 874-900. https://doi.org/10.1177/0149206305279602

Danna, K., \& Griffin, R.W. (1999). Health and well-being in the workplace: A review and synthesis of the literature. Journal of Management, 25(3), 357-384.

Deci, E.L., \& Ryan, R.M. (1995). Human agency: The basis for true self-esteem. In M.H. Kemis (Ed.), Efficacy, agency, and self-esteem (pp. 31-50). New York: Plenum.

Edwards, J.R. (1991). Person-job fit: A conceptual integration, literature review, and methodological critique. International Review of Industrial and Organizational Psychology, 6, 283-357.

Farr, J.L., \& Ford, C.M. (1990). Individual innovation. In M.A. West \& J.L. Farr (Eds.), Innovation and creativity at work: Psychological and organizational strategies (pp. 63-80). Chichester: Wiley.

Fletcher, J.K. (2004). The paradox of postheroic leadership: An essay on gender, power, and transformational change. Leadership Quarterly, 15(5), 647-661. https://doi. org/10.1016/j.leaqua.2004.07.004

Gagné, M., \& Deci, E.L. (2005). Self-determination theory and work motivation. Journal of Organizational Behavior, 26(4), 331-362.

Genero, N.P., Miller, J.B., Surrey, J., \& Baldwin, L.M. (1992). Measuring perceived mutuality in close relationships: Validation of the mutual psychological development questionnaire. Journal of Family Psychology, 6(1), 36.

Gong, Y., Huang, J.C., \& Farh, J.L. (2009). Employee learning orientation, transformational leadership, and employee creativity: The mediating role of employee creative self-efficacy. The Academy of Management Journal, 52(4), 765-778. https://doi. org/10.5465/AMJ.2009.43670890

Green, S.B. (1991). How many subjects does it take to do a regression analysis? Multivariate Behavioral Research, 26(3), 499-510. https://doi.org/10.1207/ s15327906mbr2603 7

Guay, F., Vallerand, R.J., \& Blanchard, C. (2000). On the assessment of situational intrinsic and extrinsic motivation: The Situational Motivation Scale (SIMS). Motivation and Emotion, 24(3), 175-213.

Hair, J.F., Anderson, R.E., Tatham, R.L., \& Black, W.C. (1998). Multivariate data analysis with readings, 5th ed. New York: Prentice-Hill.

Halbesleben, J.R.B., \& Buckley, M.R. (2004). Burnout in organizational life. Journal of Management, 30(6), 859-879. https://doi.org/10.1016/j.jm.2004.06.004

Hamid, S.N.A., \& Yahya, K.K. (2011). Relationship between person-job fit and personorganization fit on employees' work engagement: A study among engineers in semiconductor companies in Malaysia. Paper presented at the Annual Conference on Innovations in Business and Management London, 6, 1-30, Citeseer. 
Harackiewicz, J.M. (1979). The effects of reward contingency and performance feedback on intrinsic motivation. Journal of Personality and Social Psychology, 37(8), 1352.

Harris, K.J., \& Kacmar, K.M. (2006). Too much of a good thing: The curvilinear effect of leader-member exchange on stress. Journal of Social Psychology, 146(1), 65-84. https://doi.org/10.3200/SOCP.146.1.65-84

Hofstede, G. (2001). Culture's consequences: Comparing values, behaviors, institutions and organizations across nations. London: Sage.

Hollander, E.P. (2009). Inclusive leadership: The essential leader-follower relationship. New York: Routledge.

Honneth, A. (1995). The struggle for recognition: The moral grammar of social struggles. Cambridge: Polity.

Huhtala, H., \& Parzefall, M.R. (2007). A review of employee well-being and innovativeness: An opportunity for a mutual benefit. Creativity and Innovation Management, 16(3), 299-306. https://doi.org/10.1111/j.1467-8691.2007.00442.x

Janssen, O. (2000). Job demands, perceptions of effort-reward fairness and innovative work behaviour. Journal of Occupational and Organizational Psychology, 73(3), 287-302. https://doi.org/10.1348/096317900167038

Janssen, O. (2004). How fairness perceptions make innovative behavior more or less stressful. Journal of Organizational Behavior, 25(2), 201-215. https://doi. org/10.1002/job.238

Jung, D.I., \& Avolio, B.J. (2000). Opening the black box: An experimental investigation of the mediating effects of trust and value congruence on transformational and transactional leadership. Journal of Organizational Behavior, 21(8), 949-964.

Kanter, R.M. (1988). When a thousand flowers bloom: Structural, collective and social conditions for innovation in organization. In B. Staw, \& L.L. Cummings (Eds.), Research in organizational behaviour (pp. 167-210). Greenwich: JAI Press.

Kline, R.B. (1998). Software review: Software programs for structural equation modeling: Amos, EQS, and LISREL. Journal of Psychoeducational Assessment, 16(4), 8594. https://doi.org/10.1177/073428299801600407

Kristof-Brown, A.L., Jansen, K.J., \& Colbert, A.E. (2002). A policy-capturing study of the simultaneous effects of fit with jobs, groups, and organizations. Journal of Applied Psychology, 87(5), 985.

Kristof-Brown, A.L., Zimmerman, R.D., \& Johnson, E.C. (2005). Consequences of individuals' fit at work: A meta-analysis of person-job, person-organization, person-group, and person-supervisor FIT. Personnel Psychology, 58(2), 281342. https://doi.org/10.1111/j.1744-6570.2005.00672.x

Kuvaas, B. (2006). Work performance, affective commitment, and work motivation: The roles of pay administration and pay level. Journal of Organizational Behavior: The International Journal of Industrial, Occupational and Organizational Psychology and Behavior, 27(3), 365-385.

Kuvaas, B., Buch, R., Weibel, A., Dysvik, A., \& Nerstad, C.G.L. (2017). Do intrinsic and extrinsic motivation relate differently to employee outcomes? Journal of Economic Psychology, 61, 244-258. 
Kuvaas, B., \& Dysvik, A. (2009). Perceived investment in employee development, intrinsic motivation and work performance. Human Resource Management Journal, 19(3), $217-236$.

Lian, L.K., \& Tui, L.G. (2012). Leadership styles and organizational citizenship behavior: The mediating effect of subordinates' competence and downward influence tactics. The Journal of Applied Business and Economics, 13(2), 59-68.

Lin, Y.C., Yu, C., \& Yi, C.C. (2014). The effects of positive affect, person-job fit, and wellbeing on job performance. Social Behavior and Personality, 42(9), 1537-1547.

Linley, P.A., \& Joseph, S. (2004). Positive therapy: A positive psychological theory of therapeutic practice. In P.A. Linley, \& S. Joseph (Eds.), Positive psychology in practice (pp. 354-368). New York: John Wiley \& Sons. https://doi. org/10.1002/9780470939338

Locke, E. (1976). The nature and causes of job satisfaction. Handbook of Industrial and Organizational Psychology, 1, 1297-1343.

Lyubomirsky, S., King, L., \& Diener, E. (2005). The benefits of frequent positive affect: Does happiness lead to success? Psychological Bulletin, 131(6), 803-855. https:// doi.org/10.1037/0033-2909.131.6.803

Malhotra, N.K., Kim, S.S., \& Patil, A. (2006). Common method variance in IS research: A comparison of alternative approaches and a reanalysis of past research. Management Science, 52(12), 1865-1883. https://doi.org/10.1287/mnsc.1060.0597

Markham, S.E., Yammarino, F.J., Murry, W.D., \& Palanski, M.E. (2010). Leader-member exchange, shared values, and performance: Agreement and levels of analysis do matter. The Leadership Quarterly, 21(3), 469-480.

Mulki, J.P., Jaramillo, F., \& Locander, W.B. (2006). Emotional exhaustion and organizational deviance: Can the right job and a leader's style make a difference? Journal of Business Research, 59(12), 1222-1230.

Murray, S.L., \& Holmes, J.G. (2009). The architecture of interdependent minds: A motivation-management theory of mutual responsiveness. Psychological Review, $116(4), 908$.

Nembhard, I.M., \& Edmondson, A.C. (2006). Making it safe: The effects of leader inclusiveness and professional status on psychological safety and improvement efforts in health care teams. Journal of Organizational Behavior, 27(7), 941-966.

Nguyen, P.V, Tran, K.T., Dao, K.H., \& Dinh, H.P. (2018). The role of leader's spiritual leadership on organisation outcomes. Asian Academy of Management Journal, 23(2), 45-68. https://doi.org/https://doi.org/10.21315/aamj2018.23.2.3

Niemiec, C.P., Ryan, R.M., \& Deci, E.L. (2010). Self-determination theory and the relation of autonomy to self-regulatory processes and personality development. In R.H. Hoyle (Ed.), Handbook of personality and self-regulation (pp. 169-191). London: Blackwell.

Nix, G.A., Ryan, R.M., Manly, J.B., \& Deci, E.L. (1999). Revitalization through selfregulation: The effects of autonomous and controlled motivation on happiness and vitality. Journal of Experimental Social Psychology, 35(3), 266-284.

Quinn, R.W. (2005). Flow in knowledge work: High performance experience in the design of national security technology. Administrative Science Quarterly, 50(4), 610641, https://doi.org/10.2189/asqu.50.4.610 
Rawung, F.H., Wuryaningrat, N.F., \& Elvinita,L.E.(2015). The influence of transformational and transactional leadership on knowledge sharing: An empirical study on small and medium businesses in Indonesia. Asian Academy of Management Journal, 20(1), 123-145.

Reeve, J., Cole, S.G., \& Olson, B.C. (1986). Adding excitement to intrinsic motivation research. Journal of Social Behavior and Personality, 1(3), 349-362.

Renger, D., \& Simon, B. (2011). Social recognition as an equal: The role of equality-based respect in group life. European Journal of Social Psychology, 41(4), 501-507.

Rusbult, C.E., \& Van Lange, P.A.M. (2003). Interdependence, interaction, and relationships. Annual Review of Psychology, 54(1), 351-375.

Ryan, R.M., \& Deci, E.L. (2000a). Intrinsic and extrinsic motivations: Classic definitions and new directions. Contemporary Educational Psychology, 25, 54-67.

Ryan, R.M., \& Deci, E.L. (2000b). Self-determination theory and the facilitation of intrinsic motivation, social development, and well-being. American Psychologist, 55(1), 68-78.

Sagie, A., Elizur, D., \& Koslowsky, M. (1996). Work values: A theoretical overview and a model of their effects. Journal of Organizational Behavior, 17, 503-514.

Schaufeli, W.B., \& Bakker, A.B. (2004). Job demands, job resources, and their relationship with burnout and engagement: A multi-sample study. Journal of Organizational Behavior, 25(3), 293-315.

Schumacher, K.L., Stewart, B.J., Archbold, P.G., Caparro, M., Mutale, F., \& Agrawal, S. (2008). Effects of caregiving demand, mutuality, and preparedness on family caregiver outcomes during cancer treatment. Oncology Nursing Forum, 35(1), 49-56.

Scott, S., \& Bruce, R. (1994). Determinants of innovative behaviour: A path model of individual innovation in the workplace. The Academy of Management Journal, 37(3), 580-607. https://doi.org/10.2307/256701

Shalley, C.E., \& Gilson, L.L. (2004). What leaders need to know: A review of social and contextual factors that can foster or hinder creativity. The Leadership Quarterly, 15(1), 33-53.

Shapiro, D.L. (2010). Relational identity theory: A systematic approach for transforming the emotional dimension of conflict. American Psychologist, 65(7), 634.

Sharifirad, M.S. (2013). Transformational leadership, innovative work behavior, and employee well-being. Global Business Perspectives, 1(3), 198-225.

Shin, Y. (2004). A person-environment fit model for virtual organizations. Journal of Management, 30(5), 725-743.

Shuck, B., \& Herd, A.M. (2012). Employee engagement and leadership: Exploring the convergence of two frameworks and implications for leadership development in HRD. Human Resource Development Review, 11(2), 156-181.

Singh, R., \& Greenhaus, J.H. (2004). The relation between career decision-making strategies and person-job fit: A study of job changers. Journal of Vocational Behavior, 64(1), 198-221.

Smith, H.J., Tyler, T.R., Huo, Y.J., Ortiz, D.J., \& Lind, E.A. (1998). The self-relevant implications of the group-value model: Group membership, self-worth, and treatment quality. Journal of Experimental Social Psychology, 34(5), 470-493. 
Spreitzer, G., Sutcliffe, K., Dutton, J., Sonenshein, S., \& Grant, A.M. (2005). A socially embedded model of thriving at work. Organization Science, 16(5), 537-549.

Thomas, C.H., \& Lankau, M.J. (2009). Preventing burnout: The effects of LMX and mentoring on socialization, role stress, and burnout. Human Resource Management, 48(3), 417-432.

Tierney, P., Farmer, S.M., \& Graen, G.B. (1999). An examination of leadership and employee creativity: The relevance of traits and relationships. Personnel Psychology, 52(3), 591-620.

Tims, M., Bakker, A.B., \& Xanthopoulou, D. (2011). Do transformational leaders enhance their followers' daily work engagement? The Leadership Quarterly, 22(1), 121131.

Van den Broeck, A., Lens, W., De Witte, H., \& Van Coillie, H. (2013). Unraveling the importance of the quantity and the quality of workers' motivation for well-being: A person-centered perspective. Journal of Vocational Behavior, 82(1), 69-78.

Van Dierendonck, D. (2011). Servant leadership: A review and synthesis. Journal of Management, 37(4), 1228-1261. https://doi.org/10.1177/0149206310380462

Vinarski-Peretz, H., \& Carmeli, A. (2011). Linking care felt to engagement in innovative behaviors in the workplace: The mediating role of psychological conditions. Psychology of Aesthetics, Creativity, and the Arts, 5(1), 43.

Walumbwa, F.O., Cropanzano, R., \& Hartnell, C.A. (2009). Organizational justice, voluntary learning behavior, and job performance: A test of the mediating effects of identification and leader-member exchange. Journal of Organizational Behavior, 30(8), 1103-1126. https://doi.org/10.1002/job.611

Wang, S., \& Yi, X. (2011). It's happiness that counts: Full mediating effect of job satisfaction on the linkage from LMX to turnover intention in Chinese companies. International Journal of Leadership Studies, 6(3), 337-356.

West, M.A. (2002). Sparkling fountains or stagnant ponds: An integrative model of creativity and innovation implementation in work groups. Applied Psychology, 51(3), 355-387.

Williams, L.J., \& Anderson, S.E. (1991). Job satisfaction and organizational commitment as predictors of organizational citizenship and in-role behaviors. Journal of Management, 17(3), 601-617. https://doi.org/10.1177/014920639101700305

Wright, T.A. (2014). Putting your best "face" forward: The role of emotion-based wellbeing in organizational research. Journal of Organizational Behavior, 35(8), 1153-1168. https://doi.org/10.1002/job.1967

Wright, T.A., \& Cropanzano, R. (2000a). Psychological well-being and job satisfaction as predictors of job performance. Journal of Occupational Health Psychology, 5(1), 84-94. https://doi.org/10.1037/1076-8998.5.1.84

Wright, T.A., \& Cropanzano, R. (2000b). The role of organizational behavior in occupational health psychology: A view as we approach the millennium. Journal of Occupational Health Psychology, 5(1), 5-10. https://doi.org/10.1037/10768998.5.1.5

Wright, T.A., \& Hobfoll, S.E. (2004). Commitment, psychological well-being and job performance: An examination of conservation of resources (COR) theory and job burnout. Journal of Business \& Management, 9, 389-406. 
Xanthopoulou, D., Bakker, A.B., Demerouti, E., \& Schaufeli, W.B. (2009). Reciprocal relationships between job resources, personal resources, and work engagement. Journal of Vocational Behavior, 74(3), 235-244. https://doi.org/10.1016/j. jvb.2008.11.003

Xie, J.L., \& Johns, G. (1995). Job scope and stress: Can job scope be too high? Academy of Management Journal, 38(5), 1288-1309. https://doi.org/10.2307/256858

Yellow Pages Vietnam. (2019). Yellow Pages directory in Ho Chi Minh City, Vietnam. Ho Chi Minh City: Yellow Pages Vietnam.

Yidong, T., \& Xinxin, L. (2013). How ethical leadership influence employees' innovative work behavior: A perspective of intrinsic motivation. Journal of Business Ethics, 116(2), 441-455.

Yuan, F., \& Woodman, R.W. (2010). Innovative behavior in the workplace: The role of performance and image outcome expectations. Academy of Management Journal, 53(2), 323-342. https://doi.org/10.5465/amj.2010.49388995

Zapata-Phelan, C.P., Colquitt, J.A., Scott, B.A., \& Livingston, B. (2009). Procedural justice, interactional justice, and task performance: The mediating role of intrinsic motivation. Organizational Behavior and Human Decision Processes, 108(1), 93-105.

Zhang, X., \& Bartol, K.M. (2010). Linking empowering leadership and employee creativity: The influence of psychological empowerment, intrinsic motivation, and creative process engagement. Academy of Management Journal, 53(1), 107-128. https:// doi.org/10.5465/amj.2010.48037118 
APPENDIX

Measured Items

\begin{tabular}{|c|c|c|}
\hline Variables & Items & Items in details \\
\hline \multirow[t]{6}{*}{$\begin{array}{l}\text { Inclusive } \\
\text { leadership (IL) }\end{array}$} & IL1 & $\begin{array}{l}\text { My manager is attentive to new opportunities to improve work } \\
\text { processes }\end{array}$ \\
\hline & IL2 & $\begin{array}{l}\text { My manager is open to discuss the desired goals and new ways to } \\
\text { achieve them }\end{array}$ \\
\hline & IL3 & $\begin{array}{l}\text { My manager is available for professional questions I would like to } \\
\text { consult with him/her }\end{array}$ \\
\hline & IL4 & My manager is ready to listen to my requests \\
\hline & IL5 & My manager encourages me to access him/her on emerging issues \\
\hline & IL6 & My manager is accessible for discussing emerging problems \\
\hline \multirow{3}{*}{$\begin{array}{l}\text { Person-job fit } \\
\text { (PJF) }\end{array}$} & PJF1 & My skills and abilities perfectly match with my job demands \\
\hline & PJF2 & $\begin{array}{l}\text { My personal likes and dislikes match perfectly with my job } \\
\text { demands }\end{array}$ \\
\hline & PJF3 & There is a good fit between my job and me \\
\hline \multirow{5}{*}{$\begin{array}{l}\text { Employee well- } \\
\text { being (EWB) }\end{array}$} & EWB1 & In the past 6 months, I have felt motivated \\
\hline & EWB2 & In the past 6 months, I have felt energetic \\
\hline & EWB3 & In the past 6 months, I have felt enthusiastic \\
\hline & EWB4 & In the past 6 months, I have felt lively \\
\hline & EWB5 & In the past 6 months, I have felt joyful \\
\hline \multirow{6}{*}{$\begin{array}{l}\text { Innovative } \\
\text { behaviour (IB) }\end{array}$} & IB1 & I search out new working methods, techniques, or instruments \\
\hline & IB2 & I generate original solutions for problems \\
\hline & IB3 & $\begin{array}{l}\text { I make important organizational members enthusiastic for } \\
\text { innovative ideas }\end{array}$ \\
\hline & IB4 & I transform innovative ideas into useful applications \\
\hline & IB5 & $\begin{array}{l}\text { I introduce innovative ideas into the work environment in a } \\
\text { systematic way }\end{array}$ \\
\hline & IB6 & I evaluate the utility of innovative ideas \\
\hline \multirow{6}{*}{$\begin{array}{l}\text { Mutual } \\
\text { recognition } \\
\text { respect (MR) }\end{array}$} & MR1 & $\begin{array}{l}\text { We accept each others' right to have differing opinions even if we } \\
\text { do not agree with them }\end{array}$ \\
\hline & MR2 & We respect each others' differences \\
\hline & MR3 & We treat each other with fairness in this relationship \\
\hline & MR4 & Our working relationship has integrity and dignity \\
\hline & MR5 & We treat each other with consideration \\
\hline & MR6 & Individuals have a basic right to be respected \\
\hline
\end{tabular}




\begin{tabular}{|c|c|c|}
\hline Variables & Items & Items in details \\
\hline \multirow{4}{*}{$\begin{array}{l}\text { Intrinsic } \\
\text { motivation } \\
\text { (IM) }\end{array}$} & IM1 & The tasks that I do at work are enjoyable \\
\hline & IM2 & My job is meaningful \\
\hline & IM3 & My job is so interesting that it is a motivation in itself \\
\hline & IM4 & $\begin{array}{l}\text { Sometimes I become so inspired by my job that I almost forget } \\
\text { everything else around me }\end{array}$ \\
\hline \multirow{6}{*}{$\begin{array}{l}\text { Job } \\
\text { performance } \\
\text { (JP) }\end{array}$} & JP1 & Perform tasks that are expected of him/her \\
\hline & JP2 & $\begin{array}{l}\text { Engages in activities that will directly affect his/her performance } \\
\text { evaluation }\end{array}$ \\
\hline & JP3 & Goes out of way to help new employees \\
\hline & JP4 & Takes time to listen to coworkers' problems and worries \\
\hline & JP5 & Passes along information to co-workers. \\
\hline & JP6 & Attendance at work is above the norm. \\
\hline
\end{tabular}

